\title{
Fear as the main feature of epileptic seizures
}

\author{
A Biraben, D Taussig, P Thomas, C Even, J P Vignal, J M Scarabin, P Chauvel
}

\begin{abstract}
Objectives-There are circumstances in which partial seizures may be misdiagnosed as acute psychiatric disturbances. In particular, when fear is the prominent feature the patient may be considered for years as having panic attacks. Eight patients in whom fear was the main symptom of the seizures are reported on. Patients who had a proved lack of consciousness during the fits and patients in whom fear was just fear of having a seizure were excluded. The ictal involvement of temporal limbic and frontal structures in those patients with fear of particular intensity was studied.
\end{abstract}

Methods-The localisation of the epileptogenic zone was assessed by prolonged interictal EEG recordings as well as ictal video-EEG recording of at least one seizure in every patient; five had ictal SPECT and four had chronic stereotactic implantation of depth electrodes (SEEG). In six patients, a cortical resection was performed with an Engel's class 1 outcome (minimum 28 months follow up, except for two patients).

Results-Localisations of primary epileptogenic zones were right temporal in three patients, left temporal in three, bitemporal in one, and frontal in one. In all cases, diagnosis of epileptic seizures could be clinically evoked because of the stereotypy of fits and of associated symptoms. The association of a fear sensation, autonomic symptoms, and coordinated behaviour suggests disturbance of a particular system. The SEEG data argue for temporolimbic and prefrontal lobe involvement in the expression of ictal fear.

Conclusions-In intense ictal fear, with coordinated behaviour and autonomic features, the discharge may involve or interfere with a physiological complex information processing network. This network involves orbitoprefrontal, anterior cingulate, and temporal limbic cortices. (F Neurol Neurosurg Psychiatry 2001;70:186-191)

Keywords: fear; partial seizures; temporal lobe epilepsies; frontal lobe epilepsies

The diagnosis of partial seizures is often delayed as some of them are misdiagnosed as psychiatric disturbances. When fear is the prominent feature, the patient can be considered for years as having panic attacks. As the seizures have usually not been seen by the physician or recorded on EEG, the mistake can be responsible for therapeutic failures, as underlined by some reported cases. ${ }^{1-5}$
In the literature, ictal fear is usually associated with involvement of the amygdala ${ }^{6}$ or anterior cingulate. ${ }^{7}$ We report on eight patients in whom fear was not a vague feeling but was associated with a special behaviour and was the main symptom of the seizures. We studied the ictal involvement of temporal limbic and frontal structures in those patients.

\section{Patients and methods}

Six patients were investigated in Rennes and two in Nice. For all of them complete history, seizure description by the patient and their family, neurological examination, and MRI were available. We excluded patients in whom fear was fear of having a seizure and patients with clear lack of consciousness in every seizure. The patients had no falls during seizures. Prolonged interictal EEG recordings as well as ictal EEG recordings of at least one seizure were carried out in all patients. In every case an epileptologist or a specialised nurse examined the patient during and immediately after the seizure. Five of them had interictal and ictal single photon emission computed tomography (SPECT). Because of intractable epilepsy, four underwent chronic stereotactic implantation of depth electrodes (SEEGs), guided by individual non-invasive data according to the methodology of Talairach and Bancaud. ${ }^{8}$ One had intracarotid amobarbital testing to determine the dominant hemisphere. In the other patients, testing was not indicated as the left hemisphere was clearly dominant and no memory disorders were seen. Six had cortical resections. The extent of the resection was tailored according to the results of anatomoelectroclinical correlations. The outcome was evaluated with Engel's classification. ${ }^{9}$ We tried in each patient to correlate the appearance of the fear during the fits with electrical modification (EEG or SEEG).

\section{Results}

The demographic data are summarised in table 1. The neurological examination was normal in all. There was no personal or familial history of psychiatric disorders in any of the patients.

The clinical description of the recorded seizures is given in table 2. There was no loss of consciousness in seven patients, a possible short lasting one in patient 6. Fear and autonomic "panic attack-like " features were prominent and were the only features reported by the patient or his or her family. Ictal observation by an epileptologist showed early chewing (four) upper limb dystonia (two), leg beating (three), or a few jerks of a limb or the chin (two). These features were unknown before EEG recording. Fear always followed the initial subjective sensation or aura in the five patients who had such symptoms (table 2). 
Table 1 Demographic data

\begin{tabular}{|c|c|c|c|c|c|c|c|c|c|c|}
\hline Patient & $\begin{array}{l}\text { Age at } \\
\text { recording } \\
\text { (y) }\end{array}$ & $\operatorname{Sex}$ & $\begin{array}{l}\text { Hemispheric } \\
\text { dominance }\end{array}$ & $\begin{array}{l}\text { Epilepsy } \\
\text { c duration } \\
\text { (y) }\end{array}$ & Historical features & Social data & $\begin{array}{l}\text { Mean } \\
\text { monthly } \\
\text { seizure } \\
\text { frequency }\end{array}$ & $\begin{array}{l}\text { Generalised } \\
\text { tonic-clonic } \\
\text { seizure } \\
\text { frequency }\end{array}$ & $\begin{array}{l}\text { Daytime of } \\
\text { occurrence } \\
\text { of seizures }\end{array}$ & $\begin{array}{l}\text { Full scale } \\
\text { intelligence } \\
\text { quotient }\end{array}$ \\
\hline 1 & 14 & $\mathrm{~F}$ & $\mathrm{R}^{\star}$ & $\begin{array}{l}12 \text { years } 6 \\
\text { months }\end{array}$ & $\begin{array}{l}\text { Hyperthermic convulsions } \\
\text { Onset at } 18 \text { months after mild } \\
\text { head injury }\end{array}$ & Schoolgirl (difficulties) & 10 & 0 & Day & 93 \\
\hline 2 & 23 & $\mathrm{~F}$ & $\mathrm{~L}$ & 13 & Gravidic toxoplasmosis & Student & $1-4$ & 3/year & Day & 100 \\
\hline 3 & 12 & M & $\mathrm{L}$ & 11 & None & Schoolboy (difficulties) & 10 & 0 & Day & 80 \\
\hline 4 & 19 & $\mathrm{~F}$ & $\mathrm{~L}$ & 15 & None & Works in a laundry & $4-10$ & 0 & Night $>$ day & 65 \\
\hline 5 & 31 & $\mathrm{~F}$ & $\mathrm{~L}$ & 29 & None & Works as a nurse & $10-20$ & 0 & Day & 80 \\
\hline 6 & 12 & $\mathrm{~F}$ & $\mathrm{~L}$ & 10 & $\begin{array}{l}\text { Hyperthermic convulsions } \\
\mathrm{L} \text { polar temporal cyst derivation at } \\
\text { the age of } 3\end{array}$ & Schoolgirl (difficulties) & $15-20$ & 0 & Day>night & 78 \\
\hline 7 & 37 & $\mathrm{~F}$ & $\mathrm{~L}$ & 36 & $\begin{array}{l}\text { Hypoxic ischaemic encephalopathy } \\
\text { Hyperthermic convulsions }\end{array}$ & Housewife & 20 & $2 /$ year & Day & \multirow{2}{*}{$\begin{array}{l}\text { Not } \\
\text { performed } \\
\text { Not } \\
\text { performed }\end{array}$} \\
\hline 8 & 34 & $\mathrm{~F}$ & $\mathrm{~L}$ & 7 & Brother has epilepsy & $\begin{array}{l}\text { Hostess, presently } \\
\text { unemployed }\end{array}$ & 7 & 0 & Day & \\
\hline
\end{tabular}

${ }^{\star}$ As determined by intracarotid amobarbital testing. $\mathrm{R}=$ Right; $\mathrm{L}=$ left.

Behaviour varied considerably among the patients: two were motionless (patients 2 and 6), six were furiously agitated, five at the apparent onset, and one later who progressively lost her self control (patient 5). The subjective sensations are also different among the eight patients. Three of them feared possible hallucinations. One expressed fear during the seizure: "I feel a black shadow, like a shadow on a wall, frightening me and trying to harm me, to kill me. It is behind me. I cannot say if it is a woman or a man; it has no face. It is like a skull. I feel cold. I am going to die" (patient 5). As a child at onset of his seizures, another patient (patient 3) expressed fear saying "I'm afraid of a wolf"; more recently he did not say this but it was difficult to assess his fear postictally because of aphasia and amnesia. A few seconds after one SEEG recorded seizure, the third patient (patient 4) said that she had seen the picture of her cousin as a child lacerated with barbed wire, but she denied this 30 seconds later, forgetting why she was afraid. This may explain why she never spoke of this hallucination because she had never been asked about it soon enough after a seizure. Two patients said that they were afraid too but did not know why (patients 1 and 8). In three patients (patients 1 , 2 , and 6), facial expression and behaviour suggested fear; they asked people around them to stay with them, gripping the hand of the nearest witness. But when questioned postictally they did not express fear, perhaps because of amnesia of seizure (patient 1 ).

Localisation of the onset was definitively determined by electrophysiological and

Table 2 Seizure description

\begin{tabular}{|c|c|c|c|c|c|c|c|c|c|c|c|}
\hline Patient & $\begin{array}{l}\text { Number } \\
\text { of } \\
\text { recorded } \\
\text { seizures }\end{array}$ & $\begin{array}{l}\text { Mean }(S D) \\
\text { duration of } \\
\text { recorded } \\
\text { seizure }(s)\end{array}$ & $\begin{array}{l}\text { Autonomic } \\
\text { disturbances }\end{array}$ & $\begin{array}{l}\text { Face } \\
\text { expression }\end{array}$ & Scream & $\begin{array}{l}\text { Agitation and } \\
\text { limb automatisms }\end{array}$ & $\begin{array}{l}\text { Posturing, } \\
\text { rotation, clonic } \\
\text { movements }\end{array}$ & $\begin{array}{l}\text { Oroalimentary } \\
\text { automatisms }\end{array}$ & $\begin{array}{l}\text { Amnesia of } \\
\text { seizure }\end{array}$ & Aura & $\begin{array}{l}\text { Hands } \\
\text { in front } \\
\text { of face }\end{array}$ \\
\hline 1 & 4 & $124(20)$ & $\begin{array}{l}\text { Pallor, } \\
\text { mydriasis, } \\
\text { sometimes } \\
\text { rubefaction }\end{array}$ & $\begin{array}{l}\text { Horrified } \\
\text { (early) }\end{array}$ & $\begin{array}{l}\text { Groaning (early), } \\
\text { screaming (late), } \\
\text { shouts "stay with } \\
\text { me"(late), calls } \\
\text { for help }\end{array}$ & $\begin{array}{l}\text { Early agitation, } \\
\text { leg beating }\end{array}$ & No & $\begin{array}{l}\text { Inconstant, } \\
\text { late }\end{array}$ & $\begin{array}{l}\text { Yes; } \\
\text { remembers } \\
\text { first sensation }\end{array}$ & $\begin{array}{l}\text { Epigastric } \\
\text { sensation }\end{array}$ & Yes \\
\hline 2 & 1 & 390 & $\begin{array}{l}\text { Sensation of } \\
\text { cold, piloerection } \\
\text { on left side of } \\
\text { body; then on } \\
\text { the whole body, } \\
\text { rubefaction }\end{array}$ & $\begin{array}{l}\text { Tense, } \\
\text { preoccupied }\end{array}$ & $\begin{array}{l}\text { Sighs (late); asks } \\
\text { "I would like } \\
\text { diazepam", calls } \\
\text { for help }\end{array}$ & $\begin{array}{l}\text { No agitation, } \\
\text { mild late leg } \\
\text { automatisms }\end{array}$ & $\begin{array}{l}\text { Mild head } \\
\text { clonic } \\
\text { movements } \\
\text { (late) }\end{array}$ & $\begin{array}{l}\text { Chewing } \\
\text { late; } \\
\text { breathing }\end{array}$ & No & $\begin{array}{l}\text { Strange } \\
\text { feeling }\end{array}$ & No \\
\hline 3 & 3 & $81(8)$ & $\begin{array}{l}\text { Rubefaction, } \\
\text { then pallor, } \\
\text { mydriasis }\end{array}$ & $\begin{array}{l}\text { Horrified } \\
\text { (early) }\end{array}$ & $\begin{array}{l}\text { Screaming } \\
\text { (early) }\end{array}$ & $\begin{array}{l}\text { Early agitation } \\
\text { with leg beating } \\
\text { and hand } \\
\text { agitation }\end{array}$ & $\begin{array}{l}\text { R arm tonic } \\
\text { (once, early); } \\
\text { L periocular } \\
\text { clonic } \\
\text { movements } \\
\text { (late) }\end{array}$ & $\begin{array}{l}\text { Chewing } \\
\text { (late) }\end{array}$ & Yes & $\begin{array}{l}\text { Strange } \\
\text { feeling }\end{array}$ & Yes \\
\hline 4 & 9 & $22(4)$ & $\begin{array}{l}\text { Rubefaction, } \\
\text { mydriasis, } \\
\text { tachycardia }\end{array}$ & Horrified & $\begin{array}{l}\text { Screaming } \\
\text { (early), calls for } \\
\text { help }\end{array}$ & Early agitation & No & No & No & No & Yes \\
\hline 5 & 10 & $90(7)$ & $\begin{array}{l}\text { Thirst, cold, } \\
\text { piloerection, } \\
\text { mydriasis, pallor }\end{array}$ & $\begin{array}{l}\text { Tense, } \\
\text { preoccupied }\end{array}$ & $\begin{array}{l}\text { Says early "I } \\
\text { don't feel well" } \\
\text { then screams } \\
\text { (late), calls for } \\
\text { help }\end{array}$ & $\begin{array}{l}\text { Late agitation, } \\
\text { early leg beating }\end{array}$ & No & Early & No & $\begin{array}{l}\text { Strange } \\
\text { feeling }\end{array}$ & Yes \\
\hline 6 & 4 & $153(34)$ & $\begin{array}{l}\text { Rubefaction, } \\
\text { pallor, } \\
\text { dyspnoea, } \\
\text { tachycardia }\end{array}$ & Horrified & $\begin{array}{l}\text { No, once } \\
\text { groaning (late) }\end{array}$ & $\begin{array}{l}\text { No agitation, } \\
\text { late mild hands } \\
\text { and leg } \\
\text { automatism }\end{array}$ & $\begin{array}{l}\text { Early clonic } \\
\text { movements of } \\
\text { chin }\end{array}$ & Early & Partial & $\begin{array}{l}\text { Feels } \\
\text { something } \\
\text { in the throat }\end{array}$ & Yes \\
\hline 7 & 2 & $90(14)$ & Rubefaction & Horrified & Groaning & $\begin{array}{l}\text { Early agitation, } \\
\text { late tapping } \\
\text { with } R \text { hand }\end{array}$ & $\begin{array}{l}\text { L upper hand } \\
\text { dystonia }\end{array}$ & $\begin{array}{l}\text { Early } \\
\text { chewing }\end{array}$ & Partial & $\begin{array}{l}\text { Not } \\
\text { reported }\end{array}$ & Yes \\
\hline 8 & 5 & 67 (19) & Rubefaction & $\begin{array}{l}\text { Tense, } \\
\text { preoccupied }\end{array}$ & $\begin{array}{l}\text { Early, calls for } \\
\text { help }\end{array}$ & $\begin{array}{l}\text { Early agitation, } \\
\mathrm{L} \text { hand } \\
\text { automatism }\end{array}$ & No & Early & No & No & No \\
\hline
\end{tabular}

R=Right; L=left 
Table 3 Localisations

\begin{tabular}{|c|c|c|c|c|c|c|c|c|}
\hline Patient & MRI findings & $\begin{array}{l}\text { Interictal scalp } \\
\text { EEG }\end{array}$ & Ictal scalp EEG & Interictal SEEG & Ictal SEEG & Ictal SPECT & $\begin{array}{l}\text { Time and type of } \\
\text { cortectomy }\end{array}$ & Pathology \\
\hline 1 & Normal & Normal & $\begin{array}{l}\text { Onset : L } \\
\text { temporal }\end{array}$ & $\begin{array}{l}\text { Slow waves and } \\
\text { spikes in } \mathrm{L} \\
\text { amygdala, L post } \\
\text { hippocampus and } \\
\text { Ltemporal pole }\end{array}$ & $\begin{array}{l}\text { Onset in } \mathrm{L} \\
\text { amygdala, L post } \\
\text { hippocampus and } \\
\text { temporal pole. } \\
\text { Late invasion of } \\
\text { frontal lobe with } \\
\text { sharp waves }\end{array}$ & $\begin{array}{l}\mathrm{L} \text { temporal and } \\
\text { orbito frontal } \\
\text { hyperperfusion } \\
\text { surrounded by } \\
\text { hypoperfusion }\end{array}$ & $\begin{array}{l}\text { March 96; L } \\
\text { temporal } \\
\text { lobectomy } \\
\text { including pole }\end{array}$ & $\begin{array}{l}\text { Mesial } \\
\text { temporal } \\
\text { sclerosis }\end{array}$ \\
\hline 2 & $\begin{array}{l}\text { R Hippocampal } \\
\text { atrophy }\end{array}$ & $\begin{array}{l}\mathrm{R} \text { Temporal sharp } \\
\text { and slow waves }\end{array}$ & $\begin{array}{l}\text { Onset : R } \\
\text { temporal }\end{array}$ & ND & $\mathrm{ND}$ & $\begin{array}{l}\mathrm{R} \text { temporal } \\
\text { hyperperfusion } \\
\text { surrounded by } \\
\text { hypoperfusion }\end{array}$ & $\begin{array}{l}\text { January } 98 ; \mathrm{R} \\
\text { temporal } \\
\text { lobectomy } \\
\text { including pole }\end{array}$ & $\begin{array}{l}\text { Mild } \\
\text { neuronal loss }\end{array}$ \\
\hline 3 & $\begin{array}{l}\text { Hyperintense } \mathrm{L} \\
\text { amygdala on T2 } \\
\text { weighted images }\end{array}$ & $\begin{array}{l}\mathrm{L} \text { Temporal sharp } \\
\text { waves }\end{array}$ & $\begin{array}{l}\text { Onset : L } \\
\text { temporal }\end{array}$ & $\begin{array}{l}\text { Slow waves and } \\
\text { spikes on } \mathrm{L} \\
\text { temporal lobe, } \\
\text { internal as } \\
\text { external, as well } \\
\text { as on the internal } \\
\text { frontopolar } \\
\text { region }\end{array}$ & $\begin{array}{l}\text { Onset on L } \\
\text { amygdala, or } \\
\text { hippocampus. } \\
\text { Early implication } \\
\text { of frontopolar } \\
\text { and anterior } \\
\text { cingulate regions }\end{array}$ & $\mathrm{ND}$ & $\begin{array}{l}\text { September } 96 ; \mathrm{L} \\
\text { temporal } \\
\text { lobectomy } \\
\text { including the } \\
\text { anterior part of } \\
\text { temporal superior } \\
\text { gyrus }\end{array}$ & $\begin{array}{l}\text { Moderate } \\
\text { mesial } \\
\text { temporal } \\
\text { sclerosis }\end{array}$ \\
\hline 4 & $\begin{array}{l}\text { R Anterior } \\
\text { cingulate lesion } \\
\text { (dysplasia?) }\end{array}$ & Normal & $\begin{array}{l}\text { Onset : } \mathrm{R} \\
\text { prefrontal? } \\
\text { (artifacts) }\end{array}$ & $\begin{array}{l}\text { Spikes in } \mathrm{R} \\
\text { anterior cingulate } \\
\text { region spreading } \\
\text { to internal and } \\
\text { orbito-frontal } \\
\text { regions and to } \\
\text { temporal inferior } \\
\text { cortex }\end{array}$ & $\begin{array}{l}\text { Onset in } \mathrm{R} \\
\text { anterior cingulate } \\
\text { region spreading } \\
\text { to internal and } \\
\text { orbito-frontal } \\
\text { regions and to } \\
\text { temporal inferior } \\
\text { cortex }\end{array}$ & $\begin{array}{l}\mathrm{R} \text { frontal } \\
\text { anteromesial } \\
\text { surrounded by } \\
\text { hypoperfusion }\end{array}$ & $\begin{array}{l}\text { November } 98: \mathrm{R} \\
\text { internal frontal } \\
\text { and orbital } \\
\text { cortectomy }\end{array}$ & $\begin{array}{l}\text { Focal cortical } \\
\text { dysplasia }\end{array}$ \\
\hline 5 & Normal & $\begin{array}{l}\mathrm{R} \text { Temporal slow } \\
\text { waves }\end{array}$ & $\begin{array}{l}\text { Onset : R } \\
\text { temporofrontal }\end{array}$ & $\begin{array}{l}\text { Slow waves and } \\
\text { spikes on } \mathrm{R} \\
\text { amygdala and } \\
\text { hippocampus }\end{array}$ & $\begin{array}{l}\text { Onset on } \\
\text { amygdala, } \\
\text { associated with } \\
\text { fear. No } \\
\text { implication of } \\
\text { frontal lobe }\end{array}$ & $\begin{array}{l}\mathrm{R} \text { temporal } \\
\text { hyperpefusion } \\
\text { surrounded by } \\
\text { hypoperfusion }\end{array}$ & $\begin{array}{l}\text { November } 93 ; \mathrm{R} \\
\text { temporal } \\
\text { lobectomy } \\
\text { including pole }\end{array}$ & $\begin{array}{l}\text { Mesial } \\
\text { temporal } \\
\text { sclerosis }\end{array}$ \\
\hline 6 & $\begin{array}{l}\text { Arachnoidal cyst. } \\
\text { Hyperintense } \mathrm{L} \\
\text { temporal pole on } \\
\text { T2 weighted } \\
\text { images }\end{array}$ & $\begin{array}{l}\text { Rare } \mathrm{L} \\
\text { post-temporal } \\
\text { sharp waves }\end{array}$ & $\begin{array}{l}\text { Onset : } \mathrm{L} \\
\text { temporal }\end{array}$ & ND & ND & $\begin{array}{l}\mathrm{L} \text { temporal } \\
\text { hyperperfusion } \\
\text { surrounded by } \\
\text { hypoperfusion }\end{array}$ & $\begin{array}{l}\text { April 96; L } \\
\text { temporal } \\
\text { lobectomy }\end{array}$ & $\begin{array}{l}\text { Mesial } \\
\text { temporal } \\
\text { sclerosis }\end{array}$ \\
\hline 7 & $\begin{array}{l}\text { Bilateral temporal } \\
\text { arachnoidal cyst } \\
\mathrm{R}>\mathrm{L}\end{array}$ & $\begin{array}{l}\mathrm{R} \text { Temporal sharp } \\
\text { waves }\end{array}$ & $\begin{array}{l}\text { Onset : R } \\
\text { temporal }\end{array}$ & ND & ND & ND & ND & ND \\
\hline 8 & Normal & Normal & $\begin{array}{l}\text { Onset : R } \\
\text { temporal }\end{array}$ & ND & ND & ND & ND & ND \\
\hline
\end{tabular}

$\mathrm{R}=$ right; $\mathrm{L}=$ left; $\mathrm{ND}=$ not done.

SPECT correlations including an ictal SPECT pattern typical of temporal lobe seizure in four patients ${ }^{10}$ and suggesting frontal anteromesial onset in one (table 3). Six patients underwent cortectomy; all were seizure free (Engel class 1) at the last follow up, although the follow up was very short for two of them. The epileptogenic zone was right temporal in three right handed patients, left temporal in three including one authentic left handed patient, bitemporal in one, and right anterior mesiofrontal in one. The epileptogenic zone was thus located in the non-dominant hemisphere in six patients.

In the four patients investigated with SEEG, electrodes were implanted in the temporal and frontal lobes (especially in the anterior cingulate and orbitofrontal regions). In patient 1, fear appeared 1 minute after electrical onset of the seizure in the amygdala, when the ictal fast discharge involved the external temporal lobe and slow waves the frontal lobe. In patient 5, the ictal discharge began in temporal internal structures and fear appeared only 50 to $60 \mathrm{sec}-$ onds after the beginning of the discharge; the external temporal cortex was involved in most seizures (but not in all) showing a fast discharge at this moment. Slow waves, but never a fast discharge, were concomitant in the frontal cortex. Stimulation of amygdala evoked the fear and the sensation of a shadow behind her but without the usual ictal fear behaviour associated with a fast discharge limited to the amygdala. In patient 3, agitation appeared 30 seconds after electrical onset in limbic structures and 20 seconds after fast ictal discharge propagation in the external cortex, at a time when ictal fast discharge involved the anterior cingulate. Occasionally, the patient had an isolated discharge in the internal temporal regions associated with an isolated strange feeling but no fear. In patient 4 the SEEG recordings disclosed that fast discharges limited to the anterior cingulate region evoked palpitations simultaneously with heart rate acceleration. Fear and agitation appeared when the discharge was faster $(>50 \mathrm{~Hz})$ and more widespread, extending to the orbitofrontal region and the inferotemporal cortex. But no discharge was seen in the amygdala (figure). Electrical stimulation ( $50 \mathrm{~Hz}, 2$ seconds, $2.5 \mathrm{~mA}$ ) triggered the same electroclinical seizure if applied in the anterior cingulate, whereas stimulation of amygdala did not evoke any symptom.

In conclusion, in the four SEEG recordings, involvement of the amygdala alone did not produce fear manifestations. Fear behaviour occurred at the time when certain structures of the frontal lobe were perturbed by the ictal discharge, either directly if the discharge began or propagated in the frontal lobe (two patients), or indirectly as indicated by slow waves (two patients). 

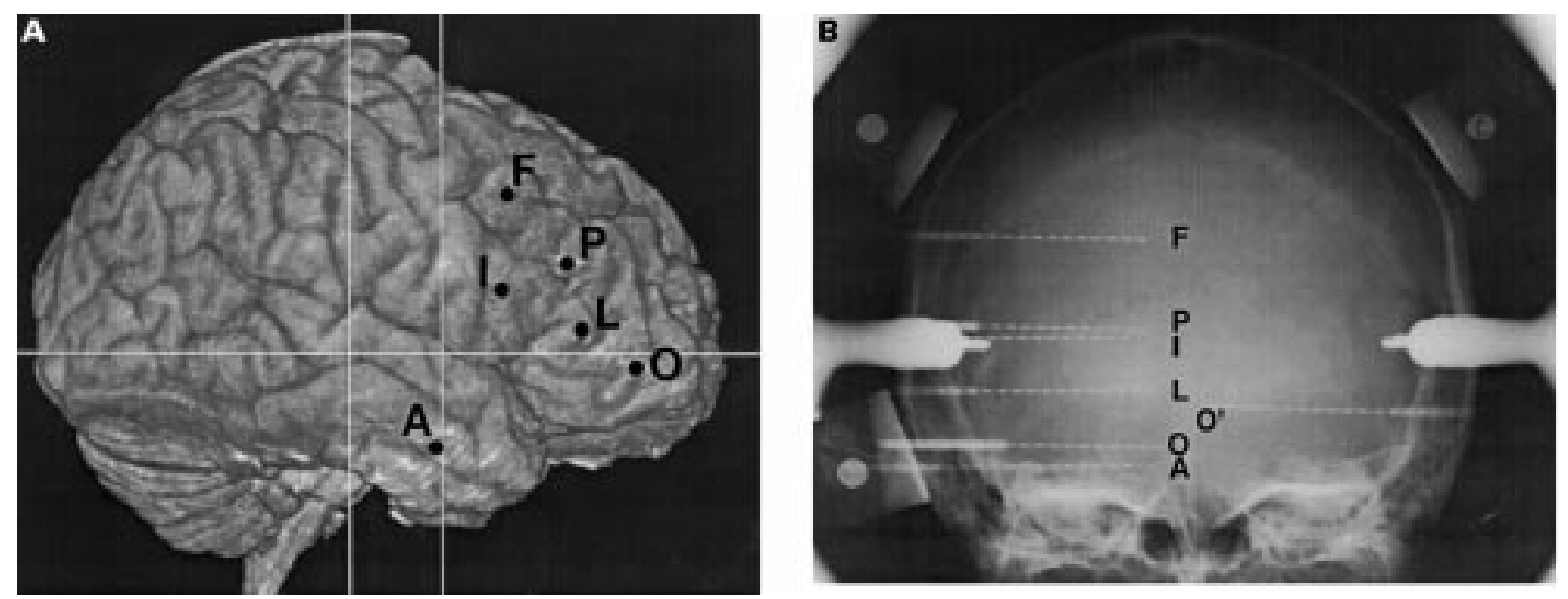

C

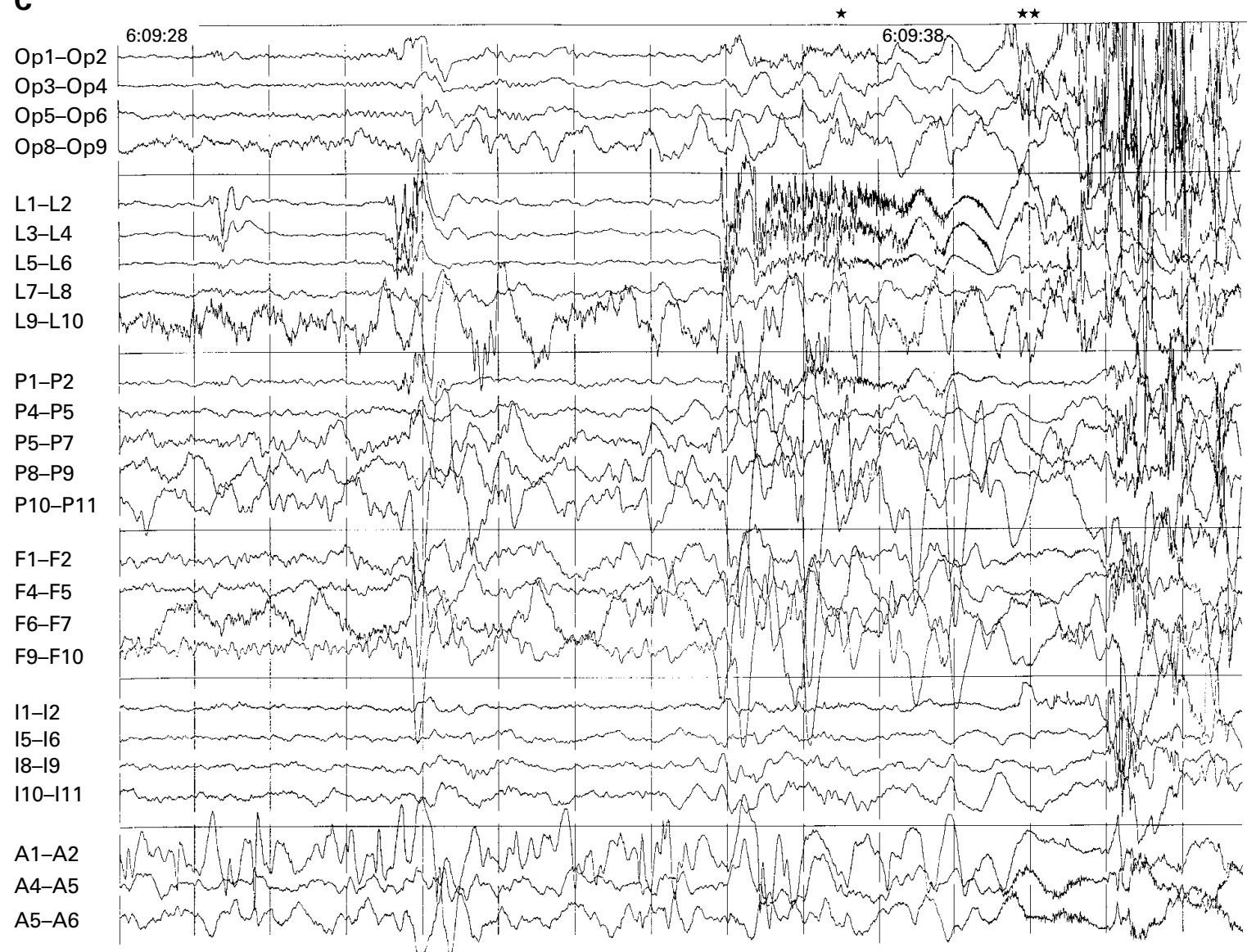

$15 \mathrm{~mm} / \mathrm{s}, 15 \mu \mathrm{V} / \mathrm{mm}, \mathrm{HFF}=\mathrm{OFF}, \mathrm{TC}=\mathrm{OFF}$, Line filter $=\mathrm{OFF}$, high res

SEEG data. (A) lateral view of the depth electrode implantation on the patient's $3 D$ MRI. (B) $x$ Ray film of the skull during depth electrode recording showing the implantation. The positions of the electrodes were determined with sterotactic landmarks in accordance with the method described by Talairach et al. ${ }^{8}$ Right electrodes: $F=$ medial frontal cortex (internal contacts), superior frontal gyrus (external contacts); $P=$ medial frontal cortex (internal contacts), middle frontal gyrus (external contacts); $L=$ within the lesion close to the anterior cingular gyrus (internal contacts), middle frontal gyrus (external contacts); $O=$ supraorbital region; $I=$ frontal opecular region; $A=$ amygdala (internal contacts), middle temporal gyrus (external contacts). Left electrode: $O$ '=facing the lesion in the anterior cingular gyrus (internal contacts), middle frontal gyrus (external contacts). (C) Seizure onset: *electrical onset with very rapid discharge on internal $L$ following interictal spikes; ${ }^{\star *}$ clinical onset with agitation, the discharge spreads to adjacent electrodes and to the temporal electrode.

\section{Discussion}

Panic attacks are characterised by a sudden, spontaneous onset of intense fear or discomfort with distressing body organ symptoms usually accompanied by thoughts of dread, impending death, or fear of being trapped, losing control, or going crazy. According to the DSM IV, ${ }^{11}$ there is no definite minimum duration to qualify as a panic attack but most clinicians consider that a few minutes is the very least. Among our patients, one (patient 2) had seizures of a duration consistent with panic attacks. The age of onset of panic disorder is in late adolescence or early adulthood. Only one of our patients had an onset later than in childhood. People with panic disorders have full 
recollection of the attacks. Half of our patients had amnesia of their seizures. In seven patients, the associated symptoms, particularly buccal automatisms, strongly suggested involvement of the internal temporal region. In the eighth case, the differential diagnosis of nightmares could be ruled out because of the short duration and frequency of the episodes. Both patients with panic attacks or partial seizures may have anticipatory anxiety about having another episode. Both may have behavioural changes related to their attacks or seizures. The differential diagnosis can usually be ruled out because of the recollection or amnesia of the episode, its duration, the age of onset, and the symptoms which occur with fear. However, in some cases, discrete episodes of fear might be consistent with either panic attacks or partial seizures. It would be then advisable to use video EEG in some cases when the differential diagnosis is difficult to establish, to note any clinical signs wich may have gone unnoticed and evidence an ictal discharge.

Fear in our series of patients was different from the isolated feeling described in temporal mesial epilepsies: a vague feeling associated with an ascending epigastric sensation. ${ }^{12}$ Fear in our patients was associated with an expressed or observed emotion, autonomic disturbances, and a complex behaviour combining a call for help, agitation (six patients), or frightened immobility (two patients). In the two patients whose fear sometimes involved a frightening hallucination, this symptom was different from an ordinary dreamy state as mental diplopia was lacking.

In epileptic patients, fear has been evoked by electrical stimulation. When the hippocampus or amygdala are stimulated, the evoked fear sensation is very different from a panic attack. ${ }^{6{ }^{12-14}}$ Bancaud et al ${ }^{7}$ stimulated the anterior cingulate and evoked complex motor behaviour and sometimes a feeling of fear in epileptic patients but the behavioural disturbances dominated the symptomatology. In our experience lower intensity stimulation of the anterior cingulate never induced fear or a fear behaviour, even though it evoked a local postdischarge.

Isolated intense fear comparable with that in one of our patients has been rarely reported as an ictal manifestation of temporal lobe epilepsy. The localisation of seizure onset in the temporal lobe has been proved by ictal scalp $E_{E G}{ }^{15}$ or deep electrode explorations and surgery results ${ }^{1-3}$ but the involvement of the frontal lobe has not been investigated. Wieser ${ }^{16}$ reported on a patient with recurrent status in which fear was one of the most relevant features. During the SEEG recording, isolated anxiety was correlated with a discharge in the right hippocampus. The visceral symptoms were more pronounced when the amygdala was involved. The author did not state what activity occurred on frontal electrodes. Almayehu et ap described two patients having parietal astrocytomas with "panic attacks as ictal manifestations of parietal lobe seizures". However, temporal and frontal structures were poorly explored and it is not known whether fear was correlated with a discharge limited to the parietal cortex or not.

In six of our eight patients (75\%), the epileptogenic zone was situated in the nondominant hemisphere. The predominance of this hemisphere, already mentioned in the early reports, ${ }^{17}$ was confirmed by interictal recordings in 15 patients who expressed their fear at the beginning of their seizures, including 13 recordings with subdural electrodes. ${ }^{18}$ We also found a clear female predominance.

Our SPECT and SEEG data give arguments for an important role of the prefrontal cortex. In our three SEEG recordings of temporal epilepsy, amygdala involvement alone did not produce fear manifestations. Agitation could be correlated with frontal lobe activity secondary to temporal discharge; this involvement or disorganisation appeared as a fast discharge only in one patient and slow waves in two others. In our patient with frontal lobe epilepsy, the amygdala was not involved; fear and panic behaviour were correlated with anterior cingulate, orbital, and neocortical temporal discharge. This ictal network is not surprising because reciprocal anatomical connections between the amygdala and orbitofrontal as well as anterior cingulate regions have indeed been proved to be strong. ${ }^{19}$

There could be three explanations to the fear behaviour in our patients. Firstly, the autonomic symptoms related to amygdala discharge could induce the secondary sensation of fear (patients 2 and 8). Secondly, the initial ictal subjective sensation could activate specific networks relying on previous experiences in the prefrontal cortex, which in turn, projects to the amygdala, anterior cingulate, and basal ganglia. They activate the autonomic nervous system, dispatch signals to the motor system, and activate endocrine and peptide systems as well as non-specific neurotransmitter nuclei in the brain stem. This would be in agreement with the theory proposed by Damasio concerning emotions $^{20}{ }^{21}$ with the changes related to "somatic markers". Thirdly, the activation of neuromodulatory nuclei in the brain stem could bypass the body, especially in known situations. The subcortical pathways activated by the epileptic discharge could directly evoke fear behaviour, even without conscious autonomic disturbances or ictal discharge in the prefrontal lobe.

A common anatomical basis for these epileptic seizures and panic attacks could be inferred from animal studies, observations in humans with lesions of the limbic regions or areas modulating limbic regions, ${ }^{22}$ and PET studies in panic attacks. ${ }^{23}{ }^{24}$ In some patients, fear can occur concomitantly as an epileptic feature and as a panic attack, as in one patient reported by Weilburg et al. ${ }^{25}$ These authors suggest that a discharging epileptic focus stimulating temporal limbic structures, especially the amygdala, may facilitate novel sensory-emotional associations.

\section{Conclusion}

Fear behaviour can predominate in certain epileptic seizures, requiring careful differential 
diagnosis with panic attacks. Our data suggest that in intense ictal fear, with coordinated behaviour and autonomal features, the discharge may involve or interfere with a physiological complex information processing network. This network involves orbito-refrontal, anterior cingulate, and temporal limbic cortices.

1 Henriksen GF. Status epilepticus partialis with fear as clinical expression. Report of a case and ictal EEG findings. Epilepsia 1973;14:39-46.

2 McLachlan RS, Blume WT. Isolated fear in complex partial status epilepticus. Ann Neurol 1980;8:639-41.

3 Devinsky O, Sato S, Theodore WH, et al. Fear episodes due to limbic seizures with normal ictal scalp EEG: a subdural electrographic study. 7 Clin Psychiatry 1989;50:28-30.

4 Laidlaw JDD, Zaw KM. Epilepsy mistaken for panic attacks in an adolescent girl. BMF 1993;306:709-10.

5 Almayehu S, Bergey GK, Barry E, et al. Panic attacks as ictal manifestations of parietal lobe seizures. Epilepsia $1995 ; 8$ : manifest

6 Gloor P, Olivier A, Quesney LF, et al. The role of the limbic system in experiential phenomena of temporal lobe epilepsy. Ann Neurol 1982;12:129-44.

7 Bancaud J, Talairach J, Geier S, et al. Manifestations comportementales induites par la stimulation électrique du gyrus cingulaire antérieur chez l'homme. Rev Neurol 1976; 132:705-24.

8 Talairach J, Bancaud J, Szikla G, et al. Approche nouvelle de la neurochirurgie de l'épilepsie. Méthodologie stéréotaxique et résultats thérapeutiques. Neurochirurgie 1974 20(suppl 1):1-249.

9 Engel JJ. Surgical treatment of epilepsies. 2nd ed. New York: Raven Press, 1993.

10 Duncan R, Patterson J, Roberts R, et al. Ictal/post ictal SPECT in the pre-surgical localisation of complex partial seizures. $\mathcal{F}$ Neurol Neurosurg Psychiatry 1993;56:141-8.
11 American Psychiatric Association-DSM-IV. Diagnostic and statistical manual of mental disorders. Washington, DC: APA, 994.

12 French JA, Williamson PD, Thadani VM, et al. Characteristics of medial temporal lobe epilepsy: I. Results of history and physical examination. Ann Neurol 1993;34:774-8.

13 Mullan S, Penfield W. Illusions of comparative interpretation and emotion. Arch Neurol Psychiatry 1959;15:269-84.

14 Halgren E, Walter RD, Cherlow DG, et al. Mental phenomena evoked by electrical stimulation of the human hippocampal formation and amygdala. Brain 1978;101:83-117.

15 Zappoli R, Zaccara G, Arnetoli G, et al. Combined partial temporal and secondary generalized status epilepticus. Eur Neurol 1983;22:192-204.

16 Wieser HG. Temporal lobe or psychomotor status epilepticus. A case report. Electroencephalogr Clin Neurophysiol 1980;48:558-42.

17 Williams D.The structure of emotions reflected in epileptic experiences. Brain 1956;79:29-67.

18 Hermann B, Wyler A, Blumer D, et al. Ictal fear: lateralizing significance and implications for understanding the neurobiology of pathological ictal fear. Neuropsychiatry, Neuropsychology, and Behavioral Neurology 1992;5:205-10.

19 Gloor P. The temporal lobe and limbic system. New York: Oxford University Press, 1997.

20 Damasio AR. On some functions of the human prefrontal cortex. Ann N Y Acad Sci 1995;769:241-51.

21 Damasio AR. Toward a neurobiology of emotion and feeling: operational concepts and hypothesis. The Neuroscientist 1995;1:19-25.

22 Kuhar M. Neuroanatomical substrates of anxiety: a brief survey. Trends Neurosci 1986;9:307-11.

23 Reiman E, Raichle M, Robins E, et al. The application of positron emisson tomography to the study of panic disorder. Am F Psychiatry 1986;143:469-77.

24 Krystal J, Deutsch D, Charney D. The biological basis of panic disorder. F Clin Psychiatry 1996;57(suppl 10):23-31.

25 Weilburg J, Bear D, Sachs G. Three patients with concomitant panic attacks and seizure disorder: possible clues to neurology of anxiety. Am $\mathcal{F}$ Psychiatry 1987;144:1053-6. 